\title{
Use of a Turbidity Sensor to Characterize Micellar Casein Powder Rehydration: Influence of Some Technological Effects
}

\author{
C. Gaiani, ${ }^{1}$ S. Banon, ${ }^{1}$ J. Scher, ${ }^{1}$ P. Schuck, ${ }^{2}$ and J. Hardy ${ }^{1}$ \\ ${ }^{1}$ Laboratoire de Science et Génie Alimentaires, 2 Avenue de la Forêt de Haye, \\ B.P. 172, 54505 Vandoeuvre Les Nancy Cedex, France \\ ${ }^{2}$ INRA, UMR Sciences et Technologies du lait et de l'œuf, 65, Rue de Saint-Brieuc, \\ 35042 Rennes, France
}

\begin{abstract}
A simplified method to study rehydration of dairy powders was developed for native phosphocaseinate powder. The method involved dispersing powder in a stirred vessel equipped with a turbidity sensor under standardized conditions. The changes of turbidity occurring during powder rehydration highlighted several stages. These stages include particles wetting, and then swelling as the water penetrates into the powder bed, followed by a slow dispersion of the particles. With this tool, some technological effects on powder rehydration were analyzed. Ultrafiltrate incorporation to the casein concentrate before spray drying was found to greatly improve the rehydration, whereas mixing ultrafiltrate powder with casein powder after spray drying did not change the rehydration properties. The effect of granulation on powder rehydration stages was also investigated.

(Key words: turbidity, native phosphocaseinate, rehydration, drying)
\end{abstract}

Abbreviation key: NPC = native phosphocaseinate.

\section{INTRODUCTION}

Rehydration is an essential quality attribute of a dairy powder because most powders are dissolved before use (King, 1966). Some common problems are associated with different stages of the rehydration process: wettability, which is the ability to absorb water; sinkability, which is the ability to sink into the water; dispersibility, which is the ability to disperse in single particles throughout the water; and solubility, which is the ability to dissolve in water (Freudig et al., 1999).

The use of a turbidity sensor to continuously follow a physicochemical process is common especially in crystallography (Crawley et al., 1996; Herri et al., 1999; Moscosa-Santillan et al., 2000) and in environmental studies

\footnotetext{
Received February 21, 2005.

Accepted April 4, 2005.

Corresponding author: Sylvie Banon; e-mail: Sylvie.Banon@ ensaia.inpl-nancy.fr.
}

(Huang and Cheng, 1996; Spicer et al., 1998). In dairy research, turbidity sensors are also used for monitoring enzymatic milk clotting and acidification (Hardy and Fanni, 1981; Hardy and Scher, 1986; Banon and Hardy, 1991). Except for the report of de Wit and Klarenbeek (1986), the use of a turbidity sensor to study rehydration stages of a dairy powder has not been reported. However, these authors did not take into account the stirring effect or the different stages occurring during rehydration.

In the present work, we used native phosphocaseinate (NPC), which is obtained by tangential membrane microfiltration of milk followed by spray drying of the diafiltrated retentate (Schuck et al., 1994). This powder is an attractive material due to its high protein content and can be used as a relevant model of milk micelles (Famelart et al., 1999). However, the low water transfer during NPC rehydration makes rehydration a time consuming step. By improving its rehydration properties, NPC would then become an attractive material for the dairy and food industry.

Rehydration properties of dairy powders have been investigated often (King, 1966; Baldwin and Sanderson, 1973; Schubert, 1993) but the rehydration process of NPC is less studied (Davenel et al., 1997; Schuck et al., 2002). The objectives of the present study were (i) to validate a turbidity sensor under standardized conditions to continuously follow NPC rehydration, (ii) to use the turbidity profiles obtained to study its rehydration, and (iii) to point out some technological factors (ultrafiltrate incorporation mode and granulation) improving its rehydration.

\section{MATERIALS AND METHODS}

\section{NPC and Ultrafiltrate Preparation}

The concentrates were supplied by Unité Mixte de Recherche: Sciences et Technologies du lait et de l'œuf (INRA Rennes, France). Native phosphocaseinate was separated from skimmed milk by tangential membrane microfiltration followed by purification through water diafiltration according to Pierre et al. (1992) and Schuck et al. (1994). Ultrafiltrate was obtained by membrane 
A.

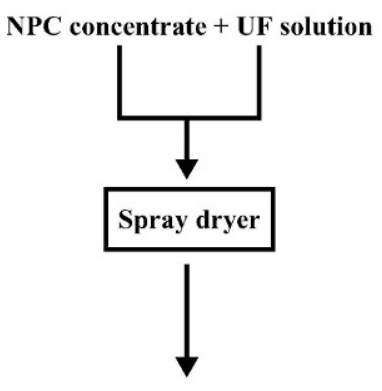

Co-drying (CD) powders

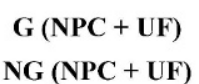

B.

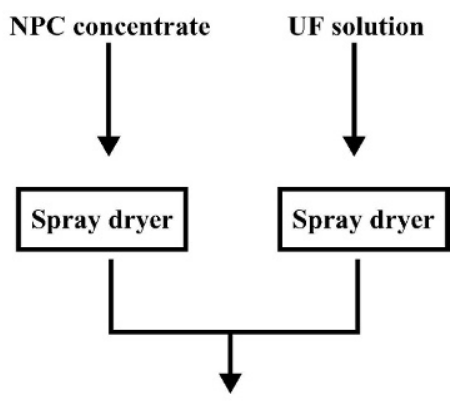

Dry-mixing (DM) powders

Figure 1. Diagrams of the 2 incorporation modes for co-drying (A) and dry-mixing (B) powders. For each method, 2 types of powders were prepared: granulate $(\mathrm{G})$ and nongranulate $(\mathrm{NG})$ powder. $\mathrm{CD}=$ Co-drying, DM = dry-mixing, $\mathrm{NPC}=$ native phosphocaseinate, $\mathrm{UF}=$ ultrafiltrate.

tangential UF of microfiltrate collected during NPC production.

\section{Vacuum Evaporation}

Ultrafiltrate was concentrated at Bionov (Rennes, France) in a 2-stage pilot plant falling film vacuum evaporator (GEA, Niro Atomizer, St-Quentin en Yvelines, France) at $530 \mathrm{~g} / \mathrm{kg}$ of total solid. Evaporation capacity was close to $300 \mathrm{~kg} / \mathrm{h}$. The temperature of the first effect was $75 \pm 1^{\circ} \mathrm{C}$ and the outlet temperature of the concentrate was $50 \pm 1^{\circ} \mathrm{C}$.

\section{Powder Preparation}

Ultrafiltrate was added to NPC according to 2 methods: co-drying and dry-mixing (Figure 1). The co-drying powder was produced by adding the UF solution to NPC concentrate before spray drying. The dry-mixing powder was produced by mixing UF powder with NPC powder after spray drying.

The spray drying of concentrates was performed at Bionov (Rennes, France) in a 3-stage pilot-plant spray dryer (GEA, Niro Atomizer) according to Schuck et al. (1998). The temperature of the concentrate before drying was at $20^{\circ} \mathrm{C}$ for the UF concentrate (after $4 \mathrm{~h}$ of crystallization), and up to $40 \pm 2^{\circ} \mathrm{C}$ for the other dairy products. The atomizer was equipped with a pressure nozzle $(0.73$ $\mathrm{mm}$ diameter orifice) and a 4 -slot core $(0.51 \mathrm{~mm}$ nominal width), providing a $60^{\circ}$ spray angle. Evaporation capacity was 70 to $120 \mathrm{~kg} / \mathrm{h}$ (depending on inlet and outlet air temperature and airflow). The pressure at the nozzle was $16 \mathrm{MPa}$. Inlet temperature was between $185 \pm 5^{\circ} \mathrm{C}$ for UF concentrate and $215 \pm 5^{\circ} \mathrm{C}$ for other concentrates, integrated fluid bed air temperature was $90^{\circ} \mathrm{C} \pm 1^{\circ} \mathrm{C}$ for UF concentrate and $70 \pm 1^{\circ} \mathrm{C}$ for other concentrates, and outlet temperature was $92 \pm 1^{\circ} \mathrm{C}$ for UF concentrate and $70 \pm 1^{\circ} \mathrm{C}$ for other concentrates. Inlet air humidity was controlled and adjusted by a dehumidifier (Munters, Sollentuna, Sweden). For each powder, 2 granulations were obtained: nongranulate and granulate powders (Figure 1) by reintroduction of the fine particles after the cyclones at the head of the spray-dryer.

\section{Chemical Analysis}

The chemical composition of the powders is reported in Table 1. The amount of total solids was determined by weight loss after drying $1-\mathrm{g}$ samples of powder at $105^{\circ} \mathrm{C}$ for $5 \mathrm{~h}$. Total protein was determined by Kjeldahl method with a 6.38 conversion factor. Lactose was determined by an enzymatic method using a Enzytec lactose/ D-galactose kit (SCIL Diagnostics GmbH, Martinsried, Germany) and fat according to the Röse-Gottlieb method by the FIL 9C:1997 (FIL-IDF, 1997). Ash were measured after incineration at $550^{\circ} \mathrm{C}$ during $5 \mathrm{~h}$.

\section{NPC Rehydration Study}

Experimental set-up. The experiments were carried out in a 2 -L vessel equipped with a 4 -blade $45^{\circ}$ impeller (R 100 impeller: $8 \mathrm{~cm}$ diameter) rotating at $400 \mathrm{rpm}$ (Lightnin LabMaster Mixer, Axflow, France). The temperature was kept constant at $24^{\circ} \mathrm{C}$ using a double-wall jacket vessel. The turbidity sensor was placed $3 \mathrm{~cm}$ under the water surface and positioned through the vessel wall to avoid disturbances during stirring.

Turbidity changes accompanying powder rehydration were followed using a turbidity meter (Analite NEP 160, McVan Instruments, Mulgrave, Australia). This apparatus used light in the near-infrared region $(860 \mathrm{~nm})$; the incident beam is reflected back at $180^{\circ}$ by any particle in suspension in the fluid to a sensitive electronic receptor. The turbidity meter was connected to a measurement system for continuous monitoring (Almemo 8990$8 V_{5}$, Ahlborn, Holzkirchen, Germany). This data logger was coupled with a PC equipped with software (AMR WinControl for Almemo). Data were collected automatically every second for $1000 \mathrm{~s}$ then every $5 \mathrm{~s}$. All runs were carried out at least in triplicate.

Samples and rehydration media. Rehydration of NPC was studied in 2 media: distilled water and UF solution. Ultrafiltrate solution was prepared from ultrafiltrate powder dissolved in distilled water $24 \mathrm{~h}$ before used. Lactose concentration was calculated to be similar 
Table 1. Chemical composition of powders. ${ }^{1}$

\begin{tabular}{llllrrr}
\hline & & \multicolumn{5}{c}{ Composition } \\
\cline { 3 - 7 } Powder (g/kg) & $\begin{array}{l}\text { Incorporation } \\
\text { mode }^{2}\end{array}$ & $\begin{array}{l}\text { Total } \\
\text { solids }\end{array}$ & $\begin{array}{l}\text { Total } \\
\text { protein }\end{array}$ & Lactose & Ash & Fat \\
\hline G NPC & - & 957.9 & 859.6 & 4.1 & 75.3 & 3.3 \\
NG NPC & - & 934.9 & 856.0 & 4.2 & 71.1 & 3.1 \\
G UF & - & 979.0 & 28.6 & 780.5 & 172.9 & ND $^{3}$ \\
NG UF & - & 980.1 & 22.3 & 776.0 & 180.3 & ND $^{3}$ \\
G (NPC+UF) & CD & 953.8 & 664.2 & 217.1 & 65.8 & 3.9 \\
(G NPC)+(G UF) & DM & 963.3 & 669.0 & 214.9 & 65.7 & ND \\
NG (NPC+UF) & CD & 935.2 & 650.9 & 207.8 & 68.8 & 5.9 \\
(NG NPC)+(NG UF) & DM & 951.5 & 661.8 & 206.5 & 67.5 & ND \\
\hline
\end{tabular}

${ }^{1} \mathrm{G}=$ Granulate NPC = native phosphocaseinate NG = nongranulate; UF = ultrafiltrate.

${ }^{2} \mathrm{CD}=$ Co-drying; $\mathrm{DM}=$ dry-mixing.

${ }^{3} \mathrm{ND}=$ Not determined.

in the UF solution and in the NPC+UF solution. In the experiments, the concentrations of powder were chosen such that total protein concentration was constant at $5 \%$ (wt/vol) for the 6 powders studied. The powder was poured into the rehydration media in less than $3 \mathrm{~s}, 30$ $\mathrm{s}$ after starting the monitoring.

\section{Static Light Scattering}

Particle size distributions were measured from a laser light diffusion apparatus (Mastersizer S, Malvern Instruments Ltd., Malvern, UK) with a 5-mW He-Ne laser operating at a wavelength of $632.8 \mathrm{~nm}$ with a $300 \mathrm{RF}$ lens.

The dry particle size distribution was determined using a dry powder feeder attachment and the standard optical model presentation for particles dispersed in air was used.

From the stirred vessel, $0.5 \mathrm{~mL}$ of casein suspension was introduced into $100 \mathrm{~mL}$ of prefiltered distilled water (Millipore, membrane diameter $0.22 \mu \mathrm{m}$ ) to reach a correct obscuration. The Malvern small volume sample cell used allowed the maintenance of a stable suspension during the measurement under stirring at $2000 \mathrm{rpm}$. The refractive indices used were 1.57 for casein and 1.33 for water (Strawbridge et al., 1995). The results obtained are average diameters calculated from Mie theory. The criterion selected was $\mathrm{d}(50)$, which means that $50 \%$ of the particles have a diameter lower than this criterion. Results are the average of 3 replicate experiments carried out on different days.

\section{Statistical Analyses}

Statistical analysis was carried out by using the software KyPlot freeware, version 2.0. For comparisons between NPC powder rehydration in water and other re- hydrations (i.e., co-drying powder in water, dry-mixing powder in water, and NPC powder in ultrafiltrate), a parametric multiple test (Dunnett test with NPC powder rehydration in water as control) was performed. The significance levels were ${ }^{* * *} P<0.001,{ }^{*} * P<0.01, * P<$ 0.05 , and ${ }^{\mathrm{NS}} P>0.05$.

\section{RESULTS}

\section{Typical Turbidity Profile During NPC Rehydration}

Typical profile. Rehydration of 5\% granulate NPC powder at $24^{\circ} \mathrm{C}$ occurred in different stages as shown in Figure 2. Dispersion of powder in the stirred vessel led to a quick increase of turbidity (peak A). Peak A was followed by a decrease of turbidity to a minimum (B) after $250 \mathrm{~s}$. Subsequent to this minimum, an increase

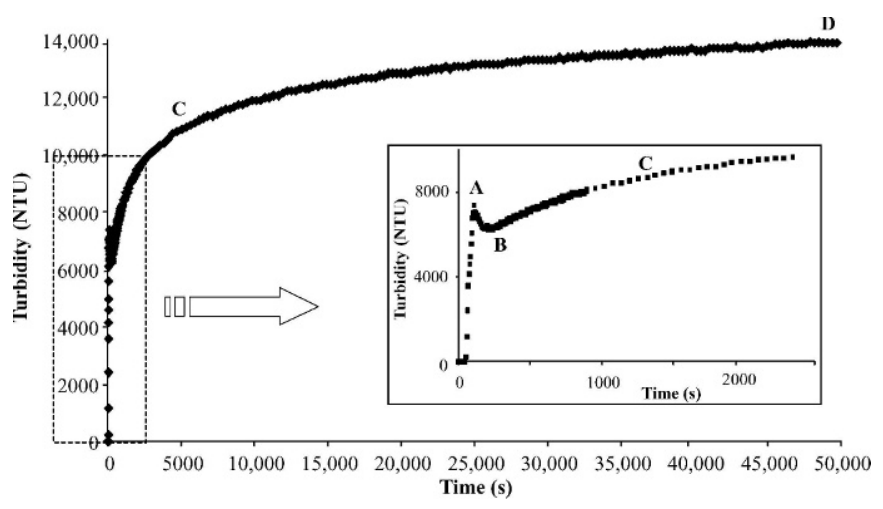

Figure 2. Turbidity typical profile as a function of time during rehydration of $5 \%$ granulate native phosphocaseinate at $24^{\circ} \mathrm{C}$ for $50,000 \mathrm{~s}$. Inset shows the first $2500 \mathrm{~s}$. A = Peak of turbidity corresponding to powder wetting; $\mathrm{B}=$ minimum of turbidity corresponding to powder swelling; $\mathrm{C}=$ turbidity increased corresponding to powder disintegration and dispersion stage; and $\mathrm{D}=$ stabilization of the turbidity corresponding to the end of rehydration. 
Table 2. Particle size diameter [d(50), $\mu \mathrm{m}]$ of native phosphocaseinate samples taken in the liquid vessel during rehydration and analyzed by static light scattering $(\mathrm{n}=3)$.

\begin{tabular}{lcc}
\hline Time, s & $\mathrm{d}(50), \mu \mathrm{m}$ & $\mathrm{SD}$ \\
\hline 0 & 286 & 4 \\
80 & 373 & 14 \\
190 & 387 & 8 \\
360 & 338 & 7 \\
900 & 257 & 8 \\
1000 & 212 & 11 \\
5000 & 134 & 8 \\
10,000 & 22 & 6 \\
15,000 & 15 & 7 \\
40,000 & 0.42 & 0.13 \\
45,000 & 0.36 & 0.08 \\
50,000 & 0.36 & 0.05 \\
60,000 & 0.36 & 0.03 \\
\hline
\end{tabular}

in turbidity occurred (phase C) from 250 to $45,000 \mathrm{~s}$. After $45,000 \mathrm{~s}$, the turbidity values stabilized around 13,000 NTU (nephelometric turbidity unit) in phase (D) when a fluid similar to milk is formed.

Particle size determination by static light scattering. During NPC rehydration, samples were taken into the stirred vessel and the $\mathrm{d}(50)$ was determined by static light scattering (Table 2). In a first phase, a swelling of the particles was observed from 286 to $387 \mu \mathrm{m}$. Following the swelling, a particle size decrease was noted with a d(50) varying from 387 to $0.36 \mu \mathrm{m}$. Above $45,000 \mathrm{~s}$, the $\mathrm{d}(50)$ stabilized at $0.36 \mu \mathrm{m}$, that is, the casein micellar size found by static light scattering (Regnault et al., 2004) and this was related to the end of rehydration.

Turbidity profile and particle size comparison. Dispersion of powder in the vessel led to a quick increase of turbidity and the time taken to reach the first turbidity peak (peak A) was related to the wetting time (Figure 3 ). Indeed, as can be observed, the turbidity signal presented a peak or a shoulder when all the particles were wetted.

The time taken to reach the minimum (B) of turbidity was related to the time taken to reach the maximal particle size (around $190 \mathrm{~s}$ ). This time is defined as the swelling time.

As a consequence of the swelling, a disintegration of the wet particles and their progressive dispersion could explain the $\mathrm{d}(50)$ decrease and consequently the turbidity increase. Phase $\mathrm{C}$ was related then to the powder dispersion.

The time for the powder to fully rehydrate was determined by the time needed to obtain turbidity stabilization (phase D). Indeed, the turbidity stabilization time around $45,000 \mathrm{~s}$ obtained with the turbidity profile is related to the particle size stabilization time obtained by static light scattering.

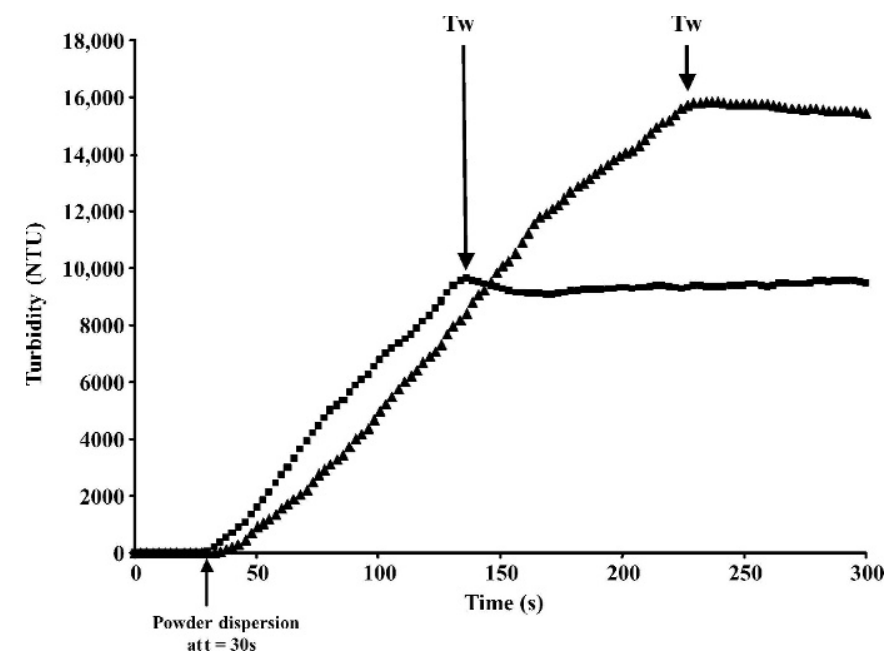

Figure 3. Turbidity profile as a function of time during rehydration of granulate native phosphocaseinate ( $\square$ ) and nongranulate native phosphocaseinate $(\boldsymbol{\Delta})$ powder at $24^{\circ} \mathrm{C}$ for $300 \mathrm{~s}$. The wetting time $(\mathrm{Tw})$ is defined as the time to reach the turbidity peak and/or shoulder.

\section{Effect of Added Ultrafiltrate on the Rehydration Process}

No ultrafiltrate added: NPC powder. The rehydration times of granulate and nongranulate NPC powders are summarized and given as a reference in Tables 3 and 4 . The wetting and swelling times were both lengthened for nongranulate NPC powder, whereas the time to rehydrate was shortened. The time to rehydrate was around $45,051 \mathrm{~s}$ for granulate and 36,138 s for nongranulate powder.

Ultrafiltrate incorporation by co-drying: $(\boldsymbol{N P C}+\boldsymbol{U F})$ powder. Ultrafiltrate powder incorporation to NPC concentrate before spray drying accelerated almost all the rehydration stages compared with NPC powders. For granulate powder (Table 3), the wetting time was not modified but the swelling time was reduced from 219 to $89 \mathrm{~s}$. Turbidity stabilization was rapidly reached and the time to rehydrate the powder was improved ( $P$ $<0.001$ ) from 45,051 for NPC to $3126 \mathrm{~s}$ for (NPC+UF).

For nongranulate powder (Table 4$)$, no differences $(P$ $>0.05$ ) were noticed for the wetting time; the time to rehydrate the powder was reduced $(P<0.001)$ from 36,138 to $1710 \mathrm{~s}$. No swelling time (minimum of turbidity) was observed. The minimum of turbidity may be masked by the quick rehydration of the powder, the swelling stage being mixed up with the wetting stage. To slow down reactions, the rehydration stages of the powder were repeated at lower temperature $\left(10^{\circ} \mathrm{C}\right.$; results not shown). All stages were lengthened and the minimum of turbidity was shown to correspond to particle swelling, confirming our hypothesis. 
Table 3. Rehydration times (in seconds) obtained for granulate powders compared with the reference powder (granulate native phosphocaseinate powder, G NPC).

\begin{tabular}{|c|c|c|c|c|c|c|c|c|}
\hline \multirow[b]{3}{*}{ Powder ${ }^{2}$} & \multirow{3}{*}{$\begin{array}{l}\text { UF } \\
\text { Incorporation } \\
\text { mode }\end{array}$} & \multirow[b]{3}{*}{ Media } & \multicolumn{6}{|c|}{ Rehydration parameters, ${ }^{1} \mathrm{~s}$} \\
\hline & & & \multicolumn{2}{|c|}{ Tw } & \multicolumn{2}{|c|}{ Ts } & \multicolumn{2}{|c|}{$\operatorname{Tr}$} \\
\hline & & & Mean & $\mathrm{SD}$ & Mean & $\mathrm{SD}$ & Mean & SD \\
\hline G NPC & - & Water & 110 & 8 & 219 & 9 & 45,051 & 1389 \\
\hline $\mathrm{G}(\mathrm{NPC}+\mathrm{UF})$ & Co-drying & Water & $88^{\mathrm{NS}}$ & 6 & $89 *$ & 11 & $3126 * * *$ & 215 \\
\hline$(\mathrm{G} \mathrm{NPC})+(\mathrm{G} U F)$ & Dry-mixing & Water & $115^{\mathrm{NS}}$ & 10 & $204^{\mathrm{NS}}$ & 55 & $44,220^{\mathrm{NS}}$ & 3200 \\
\hline G NPC & - & UF & $118^{\mathrm{NS}}$ & 15 & $244^{\mathrm{NS}}$ & 33 & $48,021^{\mathrm{NS}}$ & 4111 \\
\hline
\end{tabular}

${ }^{1} \mathrm{Tw}=$ Wetting time; $\mathrm{Ts}=$ swelling time $; \mathrm{Tr}=$ total rehydration time.

${ }^{2} \mathrm{G}=$ Granulate; NPC = native phosphocaseinate; $\mathrm{UF}=$ ultrafiltrate.

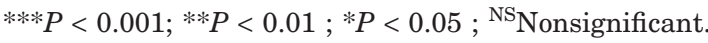

Ultrafiltrate incorporation by dry-mixing: NPC powder + UF powder. Ultrafiltrate powder incorporation after spray-drying did not improve the rehydration times. For granulate powder (Table 3), no differences $(P$ $>0.05$ ) were noticed for the wetting, swelling, and time to rehydrate. For nongranulate powders (Table 4), the swelling time was lengthened $(P<0.01)$ from 1045 to $1702 \mathrm{~s}$. The wetting time and the time to rehydrate were not modified $(P>0.05)$.

Rehydration of NPC powder in ultrafiltrate media. Rehydration of NPC in ultrafiltrate media instead of water did not change the rehydration times. For granulate powder (Table 3 ), the times obtained were not different $(P>0.05)$ from those in water. For nongranulate powders (Table 4), the swelling time was lengthened from 1045 to $1838 \mathrm{~s}$. The wetting time and the time to rehydrate were not modified $(P>0.05)$.

\section{Rehydration Times Obtained by Comparison with a Standard}

Standards for the determination of powder wettability and dispersibility are commonly used, but these are often empirical and difficult to perform (American Dry Product
Institute, 2002, and Fédération Internationale Laitière, 1985). The FIL determination of wettability consists of measuring the time necessary for all particles to absorb water in an unstirred vessel. As shown in Table 5, the wetting times obtained in our experiment correlated well with the standard wetting times. The experimental values found were always shorter than the standard values due to the stirring effect. Moreover, it is often impossible with the standard method to determine the wettability for poor-wettable powder such as nongranulate powder (time $>10,000 \mathrm{~s}$ ) in this study.

A linear relationship was found between the time to rehydrate the powder and the dispersibility (ADPI standard) as shown in Figure 4. When a powder disperses easily (high percentage of dispersibility), the time to rehydrate is shorter.

Currently, no standards are available to determine powder swelling time or rehydration time.

\section{DISCUSSION}

\section{NPC Rehydration}

From comparison of static light scattering and turbidity measurements, it appears that NPC rehydration

Table 4. Rehydration times (in seconds) obtained for nongranulate powders compared with the reference powder (nongranulate native phosphocaseinate powder, NG NPC).

\begin{tabular}{|c|c|c|c|c|c|c|c|c|}
\hline \multirow[b]{3}{*}{ Powder } & \multirow{3}{*}{$\begin{array}{l}\text { UF } \\
\text { Incorporation } \\
\text { mode }\end{array}$} & \multirow[b]{3}{*}{ Media } & \multicolumn{6}{|c|}{ Rehydration parameters, s } \\
\hline & & & \multicolumn{2}{|c|}{$\mathrm{Tw}$} & \multicolumn{2}{|c|}{$\mathrm{Ts}$} & \multicolumn{2}{|c|}{$\operatorname{Tr}$} \\
\hline & & & Mean & $\mathrm{SD}$ & Mean & $\mathrm{SD}$ & Mean & $\mathrm{SD}$ \\
\hline NG NPC & - & Water & 207 & 15 & 1045 & 39 & 36,138 & 1078 \\
\hline $\mathrm{NG}(\mathrm{NPC}+\mathrm{UF})$ & Co-drying & Water & $221^{\mathrm{NS}}$ & 22 & $\mathrm{NO}^{3, * * *}$ & 0 & 1710 **** & 110 \\
\hline$(\mathrm{NG} N \mathrm{NP})+(\mathrm{NG} U \mathrm{UF})$ & Dry-mixing & Water & $238^{\mathrm{NS}}$ & 26 & $1702 * *$ & 72 & $35,645^{\mathrm{NS}}$ & 3536 \\
\hline NG NPC & - & UF & $253^{\mathrm{NS}}$ & 34 & $1838 * *$ & 99 & $38,182^{\mathrm{NS}}$ & 1997 \\
\hline
\end{tabular}

${ }^{1} \mathrm{Tw}=$ Wetting time; $\mathrm{Ts}=$ swelling time; $\mathrm{Tr}=$ total rehydration time.

${ }^{2} \mathrm{G}=$ Granulate; $\mathrm{NPC}=$ native phosphocaseinate; $\mathrm{UF}=$ ultrafiltrate.

${ }^{3} \mathrm{NO}=$ Not observed.

$* * * P<0.001 ; * * P<0.01 ; * P<0.05 ;{ }^{\text {NS Nonsignificant }}$ 
Table 5. Wetting times obtained in our experiment compared with Fédération Internationale Laitière standard method.

\begin{tabular}{lccccc}
\hline & \multicolumn{2}{c}{$\begin{array}{c}c \\
\end{array}$} & \multicolumn{2}{c}{$\begin{array}{c}\text { Standard wetting } \\
\text { time, s }\end{array}$} \\
\cline { 2 - 3 } \cline { 5 - 6 } Powder $^{1}$ & Mean & SD & & Mean & SD \\
\hline G NPC & 110 & 8 & & 454 & 46 \\
G (NPC+UF) & 88 & 6 & & 271 & 21 \\
(G NPC)+(G UF) & 115 & 10 & & 507 & 38 \\
NG NPC & 207 & 15 & & $>10,000$ & - \\
NG (NPC+UF) & 221 & 22 & & $>10,000$ & - \\
(NG NPC)+(NG UF) & 238 & 26 & & $>10,000$ & - \\
Skim milk powder & 15 & 2 & & 66 & 13 \\
Whey protein isolate & 148 & 11 & & 780 & 67 \\
UF powder & 4 & 0 & & 15 & 2 \\
\hline
\end{tabular}

${ }^{1} \mathrm{G}=$ Granulate NPC = native phosphocaseinate; $\mathrm{UF}=$ ultrafiltrate; $\mathrm{NG}=$ nongranulate.

occurred in different stages: wetting and swelling followed by very slow dispersion of the particles to finally reach a fluid similar to milk. By viscosimetry measurements, Gaiani et al. (C. Gaiani, S. Banon, J. Scher, P. Schuck, and J. Hardy, unpublished data, 2005) noted also the wetting, swelling, and dispersion stages during NPC rehydration. By a nuclear magnetic resonance method, Davenel et al. (1997) observed 2 stages: water absorption by powder, and solubilization of particles (i.e., swelling and dispersion stages). They found an instantaneous increase of the particle hydration up to $4 \mathrm{~g}$ of water/g of powder in less than 3 min after powder pouring; our results were similar as the maximum of swelling was observed after $4 \mathrm{~min}$. The full rehydration process clearly takes time to achieve a stable dispersion. Depending on granulation, the time to rehydrate NPC powder was between 36,000 and $45,000 \mathrm{~s}$. In the study by Povey et al. (1999), casein dissolution kinetics was monitored for hours and days before complete rehydration using an ultrasound apparatus.

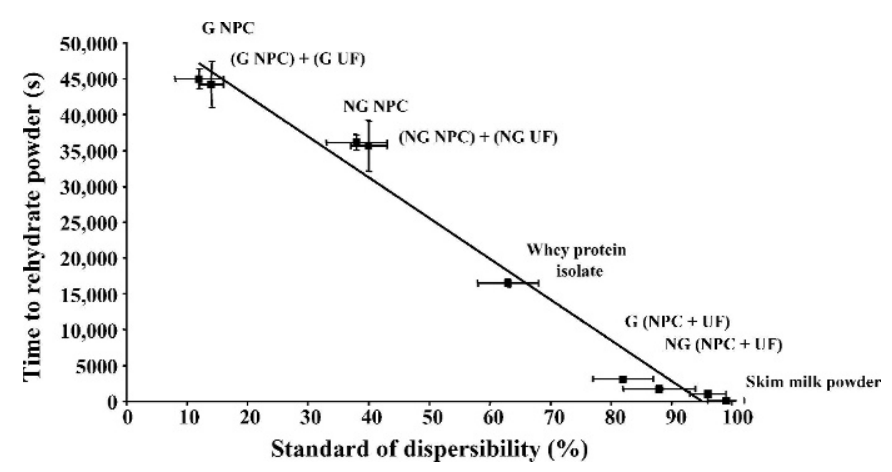

Figure 4. Relation between the dispersibility (ADPI standard) and the time to rehydrate the powder obtained in our experiment $\left(R^{2}>0.97\right) . G=$ Granulate, $\mathrm{NG}=$ nongranulate, $\mathrm{NPC}=$ native phosphocaseinate, $\mathrm{UF}=$ ultrafiltrate.

\section{Effect of Ultrafiltrate Addition on Powder Rehydration}

For co-drying powders of NPC and ultrafiltrate, the time to rehydrate was the most influenced parameter during rehydration, 14 and 20 times less for granulate and nongranulate powders, respectively. Turbidity stabilization was rapidly reached, demonstrating that the presence of ultrafiltrate favored a short rehydration. By the hygroscopic nature of UF, addition of ultrafiltrate concentrate before spray drying greatly improved water transfer in dried particles as observed by Schuck et al. (2002) when adding $\mathrm{NaCl}$ to NPC by co-drying.

Comparison of dry-mixing powders with NPC showed that the wetting and swelling time as well as the time to rehydrate were not improved. For NPC rehydration in ultrafiltrate media, similar times were obtained. As the global composition of dry-mixing NPC + UF powders in water and NPC powders in UF was the same, we hypothesized that during rehydration of dry-mixing powders, UF powder quickly rehydrated first followed by the slow rehydration of NPC powder. Rehydration of NPC in ultrafiltrate media is similar to rehydration of (NPC + UF) dry-mixing powder in water. In previous studies, Davenel et al. (1997) did not find any improvement of NPC rehydration if the incorporation of additives occurred after spray drying. On the other hand, Schuck et al. (2002) established a minor improvement of the rehydration time by dry-mixing mineral salts and NPC.

\section{Granulation Effect}

The wettability time was systematically better for granulate particles. Indeed, fast wetting is favored with large particles forming large pores, high porosity, and small contact angle between powder surface and the penetrating water. Freudig et al. (1999) found an optimal size for wettability of around $400 \mu \mathrm{m}$, close to the size of the granulate powders used in this study. The wetting stage is often described as a rate-controlling step (Schubert, 1993; Freudig et al., 1999). Baldwin and Sanderson (1973) demonstrated, for whole milk powders, that the most significant improvement in rehydration properties was obtained by improving the wetting properties. On the contrary, in our powders, the dispersion stage seemed to be the rate-controlling step. Indeed, even with a shorter wetting time, a granulate powder was slower to rehydrate than a nongranulate powder.

The time for the powder to fully rehydrate was largely influenced by the granulation, as granulation was shown to systematically slow down the rehydration process. Granulate particles penetrated the water quickly but then dispersed slowly, whereas nongranulate particles presented poor wettability (powder floated on the water surface) but then dispersed more quickly. 


\section{CONCLUSIONS}

The use of a stir vessel equipped with a turbidity sensor to continuously follow NPC rehydration was validated in this study. The interpretation of the turbidity profiles coupled with static light scattering seems to be a promising tool to appreciate casein powder rehydration and parameters like wetting time, swelling time, and rehydration time.

The experiments reported showed clearly that ultrafiltrate incorporation to NPC concentrate before spray drying improved the rehydration time and that the incorporation mode and the granulation were of importance. There is an ongoing need to develop innovative dairybased ingredients including native phosphocaseinate. By improving its rehydration properties, NPC could become an attractive material for the food industry. Co-drying of ultrafiltrate solution and NPC concentrate could be one way to extend its application. Further studies applying this approach to other dairy powders are in progress.

\section{ACKNOWLEDGMENTS}

The authors are indebted to ARILAIT RECHERCHES for stimulating discussions and financial support.

\section{REFERENCES}

ADPI. 2002. Pages 36-38 in Bulletin 916: Standards for grades of dry milks including methods of analysis. American Dry Products Institute, Elmhurst, IL.

Baldwin, A. J., and W. B. Sanderson. 1973. Factors affecting the reconstitution properties of whole milk powder. N.Z. J. Dairy Sci. Technol. 8:92-100.

Banon, S., and J. Hardy. 1991. Study of acid milk coagulation by optical method using light reflection. J. Dairy Res. 58:75-84.

Crawley, G. M., F. Gruy, and M. Cournil. 1996. In-line study of crystal fragmentation in a stirred reactor. Chem. Eng. Sci. 51:4537-4550.

Davenel, A., P. Schuck, and P. Marchal. 1997. A NMR relaxometry method for determining the reconstitutability and water-holding capacity of protein rich milk powders. Milchwissenschaft 52:35-39.

de Wit, J. N., and G. Klarenbeek. 1986. Method for the determination of rehydration and solubility of powdered protein-rich milk products. Milchwissenschaft 41:463-466.

Famelart, M. H., Y. Le Graet, and K. Raulot. 1999. Casein micelle dispersions into water, $\mathrm{NaCl}$ and $\mathrm{CaCl}_{2}$ : Physicochemical characteristics of micelles and rennet coagulation. Int. Dairy J. 9:293-297.
FIL-IDF. 1985. Détermination de la dispersibilité et de la mouillabilité. No. V04-364. Fédération Internationale Laitière-International Dairy Federation, Brussels, Belgium.

FIL-IDF. 1997. Détermination de la teneur en matière grasse-Méthode gravimétrique Röse-Gottlieb (méthode de référence). Fédération Internationale Laitière-International Dairy Federation, Brussels, Belgium.

Freudig, B., S. Hogekamp, and H. Schubert. 1999. Dispersion of powders in liquid in a stirred vessel. Chem. Eng. Process. 38:525-532.

Hardy, J., and J. Fanni. 1981. Application of reflection photometry to the measurement of milk coagulation. J. Food Sci. 46:1956-1957.

Hardy, J., and J. Scher. 1986. Mesure en continu de la coagulation du lait par une méthode optique. Pages 357-369 in Automatic Control and Optimisation of Food Processes. M. Renard and J. J. Bimbenet, ed. Elsevier Applied Science, London, UK.

Herri, J. M., F. Gruy, J. S. Pic, M. Cournil, B. Cingotti, and A. Sinquin. 1999. Interest of in situ turbidimetry for the characterization of methane hydrate crystallization: Application to the study of kinetic inhibitors. Chem. Eng. Sci. 54:1849-1858.

Huang, C., and G. S. Chen. 1996. Use of the fiber-optical monitor in evaluating the state of flocculation. Water Res. 30:2723-2727.

King, N. 1966. Dispersibility and reconstitutability of dried milk. Dairy Sci. Abstr. 28:105-118.

Moscosa-Santillan, M., O. Bals, H. Fauduet, C. Porte, and A. Delacroix. 2000 . Study of batch crystallization and determination of an alternative temperature-time profile by on-line turbidity analysis-Application to glycine crystallization. Chem. Eng. Sci. 55:3759-3770.

Pierre, A., J. Fauquant, Y. le Graet, M. Piot, and J. L. Maubois. 1992. Préparation de phosophocaséinate natif par microfiltration sur membrane. Lait 72:461-474.

Povey, M. J. W., M. Golding, D. Higgs, and Y. Wang. 1999. Ultrasonic spectroscopy studies of casein in water. Int. Dairy J. 9:299-303.

Regnault, S., M. Thiebault, E. Dumay, and J. C. Cheftel. 2004. Pressurisation of raw skim milk and of a dispersion of phosphocaseinate at $9^{\circ} \mathrm{C}$ or $20^{\circ} \mathrm{C}$ : Effects on casein micelle size distribution. Int. Dairy J. 14:55-68.

Schubert, H. 1993. Instantization of powdered food products. Int. Chem. Eng. 33:28-45.

Schuck, P., P. Piot, S. Méjean, J. Fauquant, G. Brulé, and J. L. Maubois. 1994. Déshydratation par atomisation de phophocaséinate natif obtenu par microfiltration sur membrane. Lait 74:375-388.

Schuck, P., M. Roignant, G. Brulé, S. Méjean, and J. J. Bimbenet. 1998. Caractérisation énergétique d'une tour de séchage par atomisation multiple effet. Ind. Alim. Agric. 115:9-14.

Schuck, P., A. Davenel, F. Mariette, V. Briard, S. Méjean, and M. Piot. 2002. Rehydration of casein powders: Effects of added mineral salts and salt addition methods on water transfer. Int. Dairy J. 12:51-57.

Spicer, P. T., S. E. Pratsinis, J. Raper, R. Amal, G. Bushell, and G. Meesters. 1998. Effect of shear schedule on particle size, density, and structure during flocculation in stirred tanks. Powder Technol. 97:26-34.

Strawbridge, K. B., E. Ray, F. R. Hallett, S. M. Tosh, and D. G. Dalgleish. 1995. Measurement of particle size distributions in milk homogenized by a microfluidizer: Estimation of populations of particles with radii less than $100 \mathrm{~nm}$. J. Colloid Interface Sci. 171:392-398. 